\title{
Impact of Corporate Social Responsibility on Consumer Response in Pakistan: A Mediating Role of Positive Moral Emotions, Attitude, and Consumer-Company Identification
}

\author{
Muhammad Hafeez Ullah (Corresponding Author) \\ MBA(HR). Karachi University Business School, KU Circular Rd, University of Karachi, \\ Karachi City, Pakistan \\ E-mail: mhafeezu.95@gmail.com
}

Dr. Danish Ahmed Siddiqui

Associate Professor, Karachi University Business School, KU Circular Rd, University of

Karachi, Karachi City, Pakistan

E-mail: daanish79@hotmail.com

Received: February 16, 2020 Accepted: March 26, 2020 Published: April 13, 2020

doi:10.5296/bmh.v8i1.16478 URL: http://dx.doi.org/10.5296/bmh.v8i1.16478

\begin{abstract}
Many companies and brands are using CSR to enhance the brand image, goodwill and to gain the confidence and trust of the people. The purpose of this study is to investigate how CSR initiatives got converted into consumer favorable responses. We proposed a theoretical framework, modifying Dedeke's (2015) model that hypothesized that CSR activities affect responses of the consumers towards corporate brands both directly or indirectly through mediating roles of moral emotions, attitude and consumer-company identification (CCI). Positive emotions were further broken down into awe, gratitude, and elevation, whereas consumer responses were measured in terms of purchase intention (PI), recommend intention (RI), and loyalty. To establish the empirical validity, a quantitative study was conducted, a close-ended Likert scale type questionnaire was developed whilst data were gathered from 300 adult consumers from Karachi, Pakistan by using convenient sampling. Data were analyzed using Confirmatory Factor Analysis and SEM. The results concluded that CSR has a significant positive impact directly on consumer responses (Purchase Intention, Recommend
\end{abstract}




\section{Macrothink}

Intention but not on loyalty) whereas CSR has a significant positive effect on all three positive emotions, attitudes and CCI. However, Positive Emotions have an insignificant effect on consumer responses. Apart from gratitude affecting loyalty. Hence there is a positive mediatory effect of CCI for all dimensions of customer responses. Whereas gratitude and attitude also mediate loyalty and PI respectively.

Keywords: corporate social responsibility (CSR), positive moral emotions AGE, attitude, consumer company identification (CCI), and consumer responses 


\section{Introduction}

\subsection{Background of the Study}

In this modern era of intense competition where different corporations involved in innovations and technological progress, likewise there is a new trend of corporate social responsibility persisting in the corporate world. Most of the CSR initiatives are taking place in developed countries, but today it's being implemented in emerging countries like Pakistan as well for sustainable growth. Today, both managerial functions and researchers have considered CSR as one of the most important strategic methods that yield a competitive distinction (Du, Bhattacharya, \& Sen, 2010). Since there is a huge concern for CSR actions in the general public, therefore top companies are now being involved in the activities related to public well-being and changing their business practices and more focusing on social welfare activities and CSR has now considered as the legal, legitimate and the most critical actions for business tycoons. (Wang, Chen, Yu, \& Hsiao, 2015; Gelb \& Strawser, 2001).

Past surveys have shown that consumers are more focusing on CSR activities and have set high expectations toward companies doing ethically and socially adequate duties and have deeply concerned about how CSR initiatives are effectively handled by the firms. (Dawkins \& Lewis, 2003; Schmeltz, 2012). CSR considered to be the responsibility beyond the company's interest and thus has a significant impact on the shareholders. Turker (2009) defined CSR as a duty beyond the business interest with a positive result on the shareholders. Many research studies define it as a social welfare effort, but now things are changing therefore corporate managers considered it as a strategic effort that will help them in adding values to the firms. (Staudt, Shao, Dubinsky, \& Wilson, 2014). CSR is "the commitment of the business to contribute economics developments working with employees, their households, local community, and society to a better quality of life, in ways that are both good for the business and good for development" (Chung, Yu, Choi, \& Shin, 2015).

As discussed, past scientists and employees have perceived CSR as a brand-building part in the present business settings and have discovered that CSR leads to brand trustworthiness, positive relations, perceived quality contributing comprehensively toward the improvement of brand value. Some researchers concluded that while making decisions about purchasing anything, selecting and referring the brand to others and firm credibility; CSR has the most influential effect. value (Boccia \& Sarnacchiaro, 2017; Luffarelli \& Awaysheh, 2018; Salmones, Crespo, \& Bosque, 2005). Customers will be more attracted to those corporate brands working on CSR-broadened emotional values and will be less focused on corporate brands offering competitive pricing. (Lynch \& De Chernatony, 2004). While assessing the value of two same brands, the consumers will stick to those corporate brands opting for societal actions. Therefore, academics revealed that those corporations carrying out ethical and societal activities will be enticing to consumers. (Saleh et al., 2015). Contrary to these studies, some of the researchers have identified that consumers don't make purchase decisions when companies performing CSR (Castaldo, Perrini, Misani, \& Tencati, 2010; Chomvilailuk \& Butcher, 2010). There could be many reasons behind e.g. change in taste, fashion trends, culture, expenditure, change of product choices, CSR awareness, economic 
stability and the influential impact of CSR actions consequently lead to contrary impact.

\subsection{Problem Statement}

Customers usually purchase those brand commodities or services that help solve their problems. Before buying any brand product they first evaluate the core qualities, brand corporate image, attitude, react to commercials and have some other thought-provoking aspects as well. When the consumers are aware of the corporate social responsibility actions, brand awareness eventually goes high and it induces consumer purchasing intention. (Laroche, Kim, \& Zhou, 1996; Sen \& Bhattacharya, 2001; De Wolf, Mejri, \& Lamouchi, 2012; Shim, Eastlick, Lotz, \& Warrington, 2001)

Social responsibility consumer behavior is usually the conduct of a person being socially involved and working toward social change. These consumers look for more information and data related to the brand products, consumes and disposes of it in such a way that enhances the pros and reduce some disastrous effects on the environment and the society (Mohr et al., 2001; Safi et al., 2013).

Some studies have been conducted where the conclusion of the impact of CSR on consumers is different. Some researchers have gathered information that those corporations who perform CSR activities, consumers will only buy products and will spend more whereas those corporations do not perform CSR activities, consumers will not spend money by purchasing products from them. Some academies if the corporations involved in unethical practices then they will be punished in short. Concisely you will get, what you do in return. The relationship between CSR and consumer responses is not simply a direction that suggests that there are also some variables performing a mediating function.

Thus, a question arises under what conditions CSR influences consumers. We will focus on the diversity of consumer-company identification (CCI), AGE and attitude.

\subsection{Gap Analysis}

In the early $21^{\text {st }}$ century, some of the researchers including Haidt and his colleagues identified a few of the limitations of this inquiry and hence provided an alternative based on moral emotions (Algoe \& Haidt, 2009; Haidt, 2003). Many kinds of researches have been conducted to find out the consumer emotional responses to the company's corporate social responsibility, some of the moral emotions include gratitude, elevation, pride, and guilt came out one of the key indicators of consumer responses towards the corporate brand.

This current study to fill the gap, some suggestions have been provided that include moral emotions, attitude and CCI are the most significant indicators for identifying the major effect of the company's social or ethical activities on consumer response towards the brand. Hence by adding some of the mediators like moral emotions, attitude and CCI we thus have given a stronger relationship test than some of the research studies been done in the past years when each mediator was studied individually. Precisely it means we will be holding other things constant; the impact of each mediator will be tested.

Moreover, in the previous research study where AGE was considered as positive moral 
emotions altogether whereas in this study each positive moral emotion such as awe, gratitude; and elevation are mediated between CSR and Purchase Intention, Recommend intention and loyalty individually. Hence, our work purposes to investigate the mediation effect of awe, gratitude, and elevation individually between CSR and PI, RI and loyalty which is also seen as a gap.

\subsection{Significance}

Awareness of consumer buying actions leads vendors to be familiar with their loyal buyers. Moreover, it would allow different marketers to devise appropriate advertising approaches. (Safi \& Ramay, 2013). If vendors know the purchasing actions of the buyers, they will identify in what way buyers gather information and what will be the reasons behind purchasing. (Vahdati et al., 2015).

In the business setting, the corporations can enhance the stake holder's identification with the system by doing CSR activities in Pakistan. CSR activities have a greater and significant impact along the degree of the consumers' responses. Corporations take effective CSR initiatives just after going through a substantial procedure of consumer behavior to CSR, eventually, it would affect consumer responses and work for the betterment of business functioning. Thus, our paper attempts to build a structure, including CSR, CCI, AGE, consumer responses such as PI, RI and Loyalty and analyzes using a structured questionnaire to describe the method of CSR influencing consumer responses in Pakistan. Also, giving suggestions to Pakistani companies to effectively execute CSR marketing tactics.

\subsection{Research Objective}

The core objective of conducting this study is:

- To investigate the major significant impact of corporate social responsibility activities and actions on the reaction of the consumers (purchase intention, recommend intention and loyalty) towards corporate brands directly

- To distinguish the positive influence of corporate social responsibility activities indirectly by adding mediators such as moral emotions (fear, gratitude, and elevation) on the reaction of the consumers (purchase intention, recommend intention and loyalty) indirectly

- To distinguish the positive influence of corporate social responsibility activities indirectly by adding mediator includes attitude on the reaction of the consumers (purchase intention, recommend intention and loyalty) indirectly

- To identify the positive influence of corporate social responsibility activities indirectly by adding mediator includes CCI on the response of the consumers (purchase intention, recommend intention and loyalty) indirectly 
1.6 Research Questions:

- Do CSR activities have a direct significant impact on purchase intention, recommend intention and loyalty?

- Do CSR activities have a direct significant impact on awe, gratitude; and elevation?

- Do CSR activities have a direct significant impact on attitude?

- Do CSR activities have a direct significant impact on CCI?

- Does Awe have a mediating relationship between CSR and purchase intention, recommend intention and loyalty?

- Does Gratitude have a mediating relationship between CSR and purchase intention, recommend intention and loyalty?

- Does Elevation have a mediating relationship between CSR and purchase intention, recommend intention and loyalty?

- Does Attitude have a mediating relationship between CSR and purchase intention, recommend intention and loyalty?

- Does CCI have a mediating relationship between CSR and purchase intention, recommend intention and loyalty?

\section{Literature Review}

Researchers and corporations are more focusing on CSR initiatives and the reaction to them by consumers. Corporations after doing such CSR efforts, it is still unclear how the consumers respond to their initiatives.

\subsection{CSR and Consumer Responses}

In developing countries, many researchers have examined different papers to explore consumer responses to CSR actions. Some researchers revealed that the ethical practices of companies considered a crucial part while purchasing their products. On the other hand, different studies have also been conducted to examine the impact of CSR on consumer responses in developing nations such as Pakistan. Romani et al. (2013) conducts research and reveals that a company's CSR actions influence consumer reactions to spread a positive image of the company. Ali (2011) and Sarfraz, (2014) also find out the greater impact of CSR on the intention of the consumer. Ali (2011) finds that CSR has a positive influence on consumer purchase intention. Similarly, many researchers find that CSR has also a significant impact on recommend intention and loyalty as well.

Hence based on the above studies, the following hypothesis has been proposed:

H1: There is a direct positive relationship between CSR and consumer response which are (H1a) Purchase intention; (H1b) Recommend intention; and (H1c) loyalty. 


\subsection{Elicitation of Moral Emotions, Attitudes, and CCI by CSR Activities}

\subsubsection{CSR Actions and Emotions AWE, Gratitude and Elevation}

The CSR initiatives by the companies and their performances are usually the main reason behind the evocation of the positive moral emotions AGE. Those companies evoking different feelings of elevation and awe are usually admired for doing some exemplary work done by them, and the emphasis should be on the instant emotional states from the insight of these works. Similarly, Gratitude thus defining as appreciation and a feeling of thankfulness. This feeling is induced usually when a consumer satisfied with the brand and in return, they give respect to the company by showing some gratefulness. Past study shows that corporate moral activities (Romani et al., 2013a) and corporate green activities (Xie et al., 2015) lead to felt appreciation by buyers toward organizations, in specific situations. Concisely, (AGE) form an association of felt the moral goodness and achieve a holistic halo.

H2: CSR has a direct positive relationship with the positive moral emotions AGE which is (H2a) Awe (H2b) Gratitude (H2c) Elevation

\subsubsection{CSR Actions and Attitudes}

Buying intent is the behavioral attitude of the consumer; it isn't a similar inclination the client has toward a brand, however the inspiration or cognizant method for an activity they will perform (Spears \& Singh, 2004). Lii and Lee (2012) found that there is a strong connection between the brand attitude and buying intent with regards to CSR. According to Pomering and Dolnicar (2009), CSR may be effective in eliciting favorable consumer attitudes, while recent research, like the study by López and Smith (2014), underlines that knowing which CSR domains are relevant to consumers is key to the formation of consumer preferences and attitudes, and consequently for maximizing the impact of CSR initiatives.

H3: CSR has a direct positive relationship with the attitude

\subsubsection{CSR Actions with Consumer-Company Identification}

Lichtenstein et al. (2004) revealed that when a corporation undertakes CSR initiatives, to the degree where it triggers the consumers that their personal qualities overlay with the company's qualities, the consumers may support the company. Hence those people aware of the corporations performing societal activities express a higher level of identification in comparison with those people not familiar with CSR actions. (Sen et al., 2006).

Subsequently, CSR reinforces consumers' identification towards the association and imparts inside them a feeling of belongingness towards the corporation (Matute-Vallejo et al., 2011). In a business scenario, clients who relate to an organization are bound to help its goods/services and defend its image (Siu et al., 2014). Thus, the following hypothesis is suggested:

H4: CSR has a direct positive relationship with the consumer-company identification 


\subsubsection{The Impact of AGE, Attitude, and CCI on Consumer Response}

\subsubsection{Elicitation of Awe}

Whenever organizations associate in performing those actions which are beneficial for the welfare of society and fulfilling their core duties, awe feeling must be evoked because this type of reaction is rare. In this regard, if the brand or corporations involved in corporate social responsibility initiatives and invest in the society for the betterment of people, then awe feeling will be produced in consumers and it will consequently create a positive impact on consumer response.

H5: The stronger felt awe the greater consumer response (H5a) Purchase intention; (H5b) Recommend intention; and (H5c) loyalty toward the corporate brand.

\subsubsection{Elicitation of Gratitude}

In the present research, social welfare practices bring out appreciation in consumers, and their activity inclinations are to compensate for the well-performing organization and respond emphatically toward the organization with generosity. According to Romani et al. (2013a) appreciation may be induced by corporate activities that may not legitimately benefit buyers, for example, corporate moral activities because customers see such activities as supporting at least one of their ethical sensibilities or encouraging their ethical benefits. Precisely, we recommend that actual purchaser reactions to felt positive good feelings will involve passing on a positive verbal exchange to family, companions, and family members, and opposing negative info regarding an organization. Thus,

H6: The stronger the felt gratitude the greater consumer response (H6a) Purchase intention; (H6b) Recommend intention; and (H6c) loyalty toward the corporate brand.

\subsubsection{Elicitation of Elevation}

As per the CSR settings, those potential buyers can see the organizations' consideration and funds spent on moral, natural and social issues to avoid or lessen damage to individuals; the positive feeling of elevation can result from these exercises of excellence, exemplary practices. Consumers must be encouraged to act ethically or pro-socially. In particular, we anticipate that buyers, who experience sentiments of elevation coming about because of organizations' CSR activities for the local people in which they work, are bound to take part in social activities; concerning the aim of this study, they are assessed by the amount of cash they give or the time they work voluntarily in similar networks. Romani and Grappi (2014) found that company CSR activities lead to feelings of elevation by consumers. Therefore, this feeling could be crucial in clarifying customers' reactions, for example, PI, RI, and promise to CSR in a cultural setting.

H7: The stronger the felt elevation the greater consumer response (H7a) Purchase intention; (H7b) Recommend intention; and (H7c) loyalty toward the corporate brand.

\subsubsection{Mediating Role of Attitude}

Many research studies have been examined which revealed that loyal consumers set high 


\section{An Macrothink}

expectations and will be more attracted to those corporate brands performing CSR activities in terms of higher brand attitude. Attitude is the most essential part since it predicts consumer purchasing intention. Corporations should identify trustworthy consumers and their brand perception. It shows the likes and dislikes hence it's helpful in understanding purchasing

intention. Sen et al. (2006) identify that CSR activities will evoke buyer constructive responses in other extents than the investment domain. Thus, we suggest that attitude encourages PI, RI, and loyalty

H8: The more positive the attitudes toward the company, the greater consumer responses (H8a) Purchase intention; (H8b) Recommend intention; and (H8c) loyalty toward the corporate brand.

\subsubsection{Mediating Role of CCI}

C-C Identification brings about a progressively good view towards the organization ( $\mathrm{He} \& \mathrm{Li}$, 2011); regardless of whether consumer desires are not met by the products or services offered by the organization, the buyer will be less dissatisfied if $\mathrm{C}-\mathrm{C}$ Identification is solid (Perez \& del Bosque, 2015) Surveys have been proved that once consumers identify a corporation, they develop some mental association to it, even make no differentiation between "you" and "me" and share a mutual stake. This kind of enthusiastic association can move purchasers to put more exertion to comprehend the end of the corporate willfully. Hence CCI more influences buyers' reactions to CSR, particularly may cause extra-job conduct.

In this way, following the past request, we offer the accompanying speculations:

H9: The stronger the CCI connection, the greater consumer responses (H9a) Purchase intention; (H9b) Recommend intention; and (H9c) loyalty towards a corporate brand 


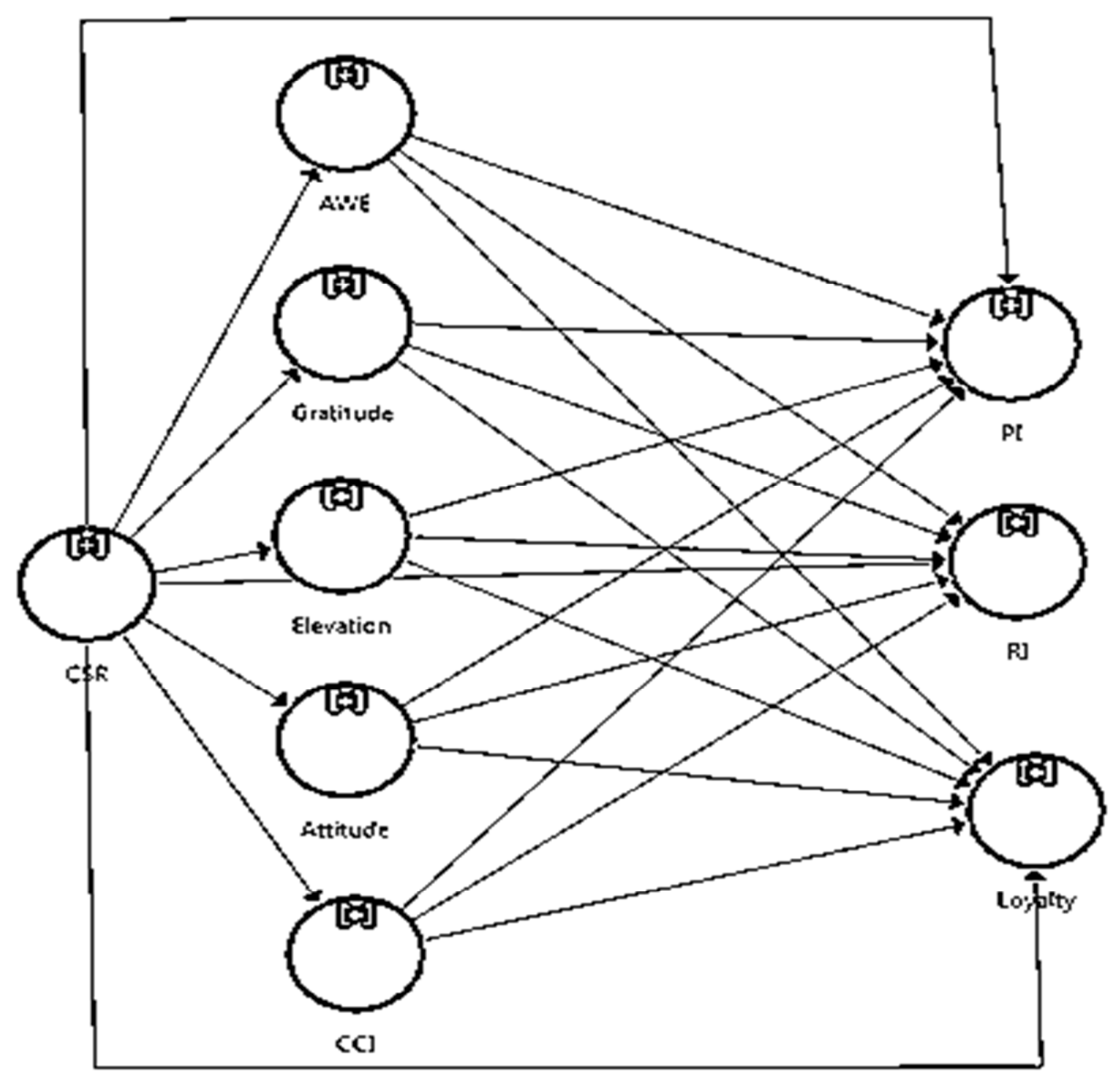

Figure 1. Conceptual Model

Source: Own research work processed in PLS-SEM

Note: AGE=awe, gratitude, elevation; Consumer responses comprise purchase intention, recommend intention and loyalty.

\section{Methodology}

\subsection{Sampling Design}

The sample consists of 300 respondents and data was gathered via convenience testing that is a non-probability examining strategy. An organized survey was intended for the collection of research information by using the previously mentioned scholars. Pakistani consumers purchasing products from those top corporations expending in CSR and were asked to meet the given questionnaires. Moreover, the questionnaire was spread via the internet for further data collection. 160 questionnaires were filled online whereas 140 questionnaires were distributed to the consumers in Karachi. 


\subsection{Instrument}

In our research, we have considered a structured survey to get more respondents in a constrained timespan. The survey contains two foremost parts, which were initially planned in English words. It is an essential information assortment strategy in research and delivers quantitative information.

Section A comprises of questions related to the demographics of a respondent, including age, gender, working experience, education, and professional level. The age limit given to have opted from a nominal scale is 21-30 years to 60 and above. Respondents are classified on gender bases as male and female. The educational level given is undergraduate, graduate and postgraduate.

Section B is composed of 26 main questions to measure 6 variables by seven-point Likert scales. Altogether the 26 main items adapted from the previous studies in which, first three questions are to measure corporate social responsibility (IV), six for positive moral emotions AGE (MV), two for attitude (MV), four for CCI (MV) and nine for consumer response (DV). Respondents could agree or disagree on the provided seven-point Likert-type scale. The questions are planned accordingly to help in guiding the research and to get the required information and provide feasibility in analyzing research.

\subsection{Measurement}

Table 1. Measurement Table

\begin{tabular}{lll}
\hline Variable measurement & Sources & No of items \\
\hline CSR & Herpen et al. (2003), Brown and Dacin et al. (1997) & 3 \\
Positive Moral & Romani \& Grappi et al. (2014) and Xie et al. (2015). & 6 \\
Emotions AGE & & \\
Attitude & Dabholkar and Bagozzi et al. (2002) & 2 \\
CCI & Mael and Ashforth et al. (1992) and Wu and Tsai et al. (2007) & 4 \\
Purchase Intention & Zeithaml et al. (1996) & 3 \\
Recommend Intention & Zeithaml et al. (1996) & 3 \\
Loyalty & Netemeyer et al. (2004) & 3 \\
\hline
\end{tabular}

In the above table, we have presented the independent, mediator and dependent variables having 26 items that are adapted from different authors. Independent variable which includes corporate social responsibility, mediator variables include positive moral emotions AGE, attitude and consumer-company identification whereas consumer response is our dependent variable having three variables purchase Intention, recommend Intention, loyalty. 


\section{Mll Macrothink}

\section{Analysis and Results}

\subsection{Demographic Information}

The demographic information indicates that most of the respondents are male $57.6 \%$ and female respondents are $41 \%$. Most of the respondents $73 \%$ are between 21 to 30 years of age while $14.6 \%$ are from the age set of 31 to 40 years. $9.3 \%$ are from the age group of 41 to 50 and $3 \%$ are in between 51 to 60 years of age. The education level of respondents is under graduation, graduation, and post-graduation $12.6 \%, 41.7 \%$, and $39.7 \%$ respectively.

Table 2. Respondents Profile

\begin{tabular}{llll}
\hline Name of Demographic & Demographic Features & Frequency & Percentage \\
\hline Age & $21-30$ & 219 & $73 \%$ \\
& $31-40$ & 44 & $14.6 \%$ \\
& $41-50$ & 28 & $9.3 \%$ \\
Gender & $51-60$ & 9 & $3 \%$ \\
& 60 and above & None & None \\
Education & Male & 177 & $57.6 \%$ \\
& Female & 123 & $41 \%$ \\
& Under graduation & 38 & $12.6 \%$ \\
& Graduation & 143 & $47.7 \%$ \\
\hline
\end{tabular}

Source: Own research work processed in PLS-SEM 
4.2 Descriptive Statistic

Table 3. Descriptive Data

\begin{tabular}{|c|c|c|c|c|c|c|c|}
\hline \multirow[t]{2}{*}{ Variables } & \multicolumn{2}{|c|}{ Questions } & \multicolumn{2}{|c|}{ Descriptive Stats } & \multicolumn{3}{|c|}{ Confirmatory Factor Analysis } \\
\hline & & & Mean & STD & Outer Loading & T Stats & P Values \\
\hline \multirow[t]{3}{*}{ CSR } & 1 & CSR1 & 5.157 & 1.465 & 0.894 & 52.81 & 0.000 \\
\hline & 2 & CSR2: & 5.247 & 1.364 & 0.911 & 57.25 & 0.000 \\
\hline & 3 & CSR3: & 5.170 & 1.330 & 0.895 & 48.87 & 0.000 \\
\hline \multirow[t]{2}{*}{ AWE } & 4 & Awe1: & 4.960 & 1.240 & 0.890 & 34.58 & 0.000 \\
\hline & 5 & Awe2: & 4.920 & 1.262 & 0.913 & 25.51 & 0.000 \\
\hline \multirow[t]{2}{*}{ Gratitude } & 6 & Gratitude1: & 5.153 & 1.271 & 0.939 & 110.21 & 0.000 \\
\hline & 7 & Gratitude2: & 5.053 & 1.313 & 0.931 & 80.53 & 0.000 \\
\hline \multirow[t]{2}{*}{ Elevation } & 8 & Elevation1: & 4.803 & 1.205 & 0.887 & 41.00 & 0.000 \\
\hline & 9 & Elevation2: & 4.703 & 1.204 & 0.841 & 22.82 & 0.000 \\
\hline \multirow[t]{2}{*}{ Attitude } & 10 & Att1: & 5.213 & 1.236 & 0.889 & 48.67 & 0.000 \\
\hline & 11 & Att2 & 5.060 & 1.297 & 0.874 & 34.58 & 0.000 \\
\hline Consumer & 12 & CCI1: & 4.790 & 1.442 & 0.792 & 25.51 & 0.000 \\
\hline Company & 13 & CCI2: & 4.693 & 1.519 & 0.855 & 38.66 & 0.000 \\
\hline \multirow[t]{2}{*}{ Identification } & 14 & CCI3: & 4.677 & 1.402 & 0.794 & 20.15 & 0.000 \\
\hline & 15 & CCI4: & 4.877 & 1.315 & 0.794 & 26.90 & 0.000 \\
\hline Purchase & 16 & P1: & 5.087 & 1.351 & 0.872 & 46.51 & 0.000 \\
\hline \multirow[t]{2}{*}{ Intention } & 17 & P2: & 5.177 & 1.291 & 0.836 & 26.20 & 0.000 \\
\hline & 18 & P3: & 5.180 & 1.294 & 0.834 & 28.07 & 0.000 \\
\hline Recommend & 19 & R1: & 5.087 & 1.211 & 0.869 & 35.16 & 0.000 \\
\hline \multirow[t]{2}{*}{ Intention } & 20 & R2: & 5.023 & 1.274 & 0.871 & 41.57 & 0.000 \\
\hline & 21 & R3: & 4.963 & 1.263 & 0.834 & 24.54 & 0.000 \\
\hline \multirow[t]{3}{*}{ Loyalty } & 22 & L1: & 4.320 & 1.380 & 0.195 & 1.41 & 0.159 \\
\hline & 23 & L2: & 4.637 & 1.338 & 0.838 & 23.35 & 0.000 \\
\hline & 24 & L3: & 4.640 & 1.292 & 0.871 & 39.12 & 0.000 \\
\hline
\end{tabular}

Source: Own research work processed in PLS-SEM

\subsection{Descriptive Analysis}

The mean of the variables mentioned above range from 4.320 to 5.247 and SD from 1.204 to 1.380. Similarly, the mean of all the three items of the independent variable i.e. CSR range from 5.157 to 5.247 whereas SD 1.330 to 1.465 . There are six items of the mediator positive moral emotions AGE and all the value of the mean range from 4.703 to 5.153 and SD 1.204 to 1.313. Likewise, two items from attitude and four items from CCI, their mean value range from 5.060 to 5.213 and 4.677 to 4.877 whilst SD range from 1.236 to 1.297 and 1.315 to 1.519 respectively. The dependent variable consumer response further divided into three sub-parts PI, RI, and loyalty. The mean and SD value of all three items from PI is in the range 5.087 to 5.180 
and 1.291 to 1.351 , three items for recommend intention and their mean and SD lie in the range 4.963 to 5.087 and 1.211 to 1.274 whereas three items from loyalty were taken and their mean value range 4.320 to 4.640 and SD value 1.292 to 1.380 . The mean of the loyalty L1 is too low and not in the range and SD value is too high which revealed that this item not meeting the criteria of mean and SD. A table of descriptive statistics also mentioned loadings used in (CFA) confirmatory factor analysis. Construct with the loading of.5 are considered as strong loading variables, whereas the constructs with the loading of below. 5 are considered as less and insignificant. In the above table the factor loadings of all items exceed 0.05 range from 0.072 to 0.939 excluding one item of loyalty which is less than 0.05 similarly, all the $\mathrm{T}$ and $\mathrm{P}$ values of the items are significant range from 20.15 to $110.21(\mathrm{~T}>1.96)$ and $\mathrm{P}<0.01$ except $\mathrm{L} 1$ $(\mathrm{T}<1.96)$ and $\mathrm{P}>0.01$.

\subsection{Reliability and Convergent Validity}

To find out the reliability and steadiness of data, Cronbach's alpha by following Anderson and Gerbing (1988) has been used and for the validity as per Hair et al. (2006). Convergent validity consists of three things: (1) factor loadings must exceed 0.5 ; (2) CR index should be higher than 0.7 ; (3) AVE must be higher than 0.50. CFA is also been conducted via PLS-SEM to measure construct validity.

Table 4 illustrates the Cronbach's value for CSR (0.88), positive moral emotions AGE Awe (0.77), Gratitude (0.857), elevation (0.66), attitude (0.71), consumer-company identification $(0.82)$, and consumer response loyalty $(0.46)$, purchase intention and recommend intention $(0.80),(0.82)$ respectively. All the values are greater than 0.70 indicated by (Hair, Anderson, Tatham, and William, 2010). With PLS, all the factor loading of greater than (0.71) should be achieved. The loadings of each latent construct are higher than the significant value of $(0.7)$ except one item of loyalty (0.19) which is insignificant and not meeting the desired value of (0.7). All the composite reliability values range from 0.87 to 0.93 which exceeds the limit of 0.7 given by Bagozzi and Yi (1988), VIF values were calculated to find interdependence hence the values were ranging from 1.29 to 2.67 which do not exceed the value of 5 as per Hair et al. (2010). The average variance extracts (AVEs) range from 0.6 to 0.8 , which meets the criteria i.e. values must be greater than 0.5 (Chin, 1998). When all the values of AVE and average $\mathrm{CR}$ meeting the desired requirement, we can say that $\mathrm{CR}$ of the model been made. 
Table 4. Reliability and Convergent Validity

\begin{tabular}{|c|c|c|c|c|c|}
\hline Variables & Items & $\begin{array}{l}\text { Factor } \\
\text { Loading }\end{array}$ & $\begin{array}{l}\text { Cronbach's } \\
\text { Alpha }\end{array}$ & $\begin{array}{l}\text { Composite } \\
\text { Reliability }\end{array}$ & $\begin{array}{l}\text { Average } \\
\text { Variance } \\
\text { Extracted }\end{array}$ \\
\hline \multicolumn{6}{|c|}{ Corporate Social Responsibility } \\
\hline \multirow[t]{3}{*}{ CSR } & CSR1 & 0.894 & 0.883 & 0.928 & 0.810 \\
\hline & CSR2 & 0.911 & & & \\
\hline & CSR3 & 0.895 & & & \\
\hline \multicolumn{6}{|c|}{ Positive Moral Emotions AGE } \\
\hline \multirow[t]{2}{*}{ Awe } & A1 & 0.890 & 0.770 & 0.897 & 0.813 \\
\hline & $\mathrm{A} 2$ & 0.913 & & & \\
\hline \multirow[t]{2}{*}{ Gratitude } & G1 & 0.939 & 0.857 & 0.933 & 0.875 \\
\hline & $\mathrm{G} 2$ & 0.931 & & & \\
\hline \multirow[t]{2}{*}{ Elevation } & E1 & 0.887 & 0.663 & 0.855 & 0.747 \\
\hline & E2 & 0.841 & & & \\
\hline \multicolumn{6}{|l|}{ Attitude } \\
\hline \multirow[t]{2}{*}{ Attitude } & AT1 & 0.889 & 0.714 & 0.875 & 0.778 \\
\hline & AT2 & 0.874 & & & \\
\hline \multicolumn{6}{|c|}{ Consumer-Company Identification } \\
\hline \multirow[t]{4}{*}{$\mathrm{CCI}$} & CCI1 & 0.792 & 0.824 & 0.883 & 0.655 \\
\hline & $\mathrm{CCI} 2$ & 0.855 & & & \\
\hline & $\mathrm{CCI} 3$ & 0.794 & & & \\
\hline & $\mathrm{CCI} 4$ & 0.794 & & & \\
\hline \multicolumn{6}{|c|}{ Consumer Response } \\
\hline \multirow[t]{3}{*}{ Loyalty } & L1 & 0.195 & 0.465 & 0.707 & 0.500 \\
\hline & L2 & 0.838 & & & \\
\hline & L3 & 0.871 & & & \\
\hline Purchase & PI1 & 0.872 & 0.804 & 0.884 & 0.718 \\
\hline \multirow[t]{2}{*}{ Intention } & PI2 & 0.836 & & & \\
\hline & PI3 & 0.834 & & & \\
\hline Recommend & RI1 & 0.869 & 0.804 & 0.893 & 0.736 \\
\hline \multirow[t]{2}{*}{ Intention } & RI2 & 0.871 & & & \\
\hline & RI3 & 0.834 & & & \\
\hline
\end{tabular}

Source: Own research work processed in PLS-SEM 
4.5 Discriminant Validity

Table 5. Discriminant Validity

\begin{tabular}{llllllllll}
\hline & AWE & Attitude & CCI & CSR & Elevation & Gratitude & Loyalty & PI & RI \\
\hline AWE & 0.901 & & & & & & & & \\
Attitude & 0.526 & 0.882 & & & & & & & \\
CCI & 0.496 & 0.535 & 0.809 & & & & & & \\
CSR & 0.552 & 0.639 & 0.467 & 0.900 & & & & & \\
Elevation & 0.526 & 0.347 & 0.480 & 0.375 & 0.864 & & & & \\
Gratitude & 0.666 & 0.448 & 0.438 & 0.463 & 0.661 & 0.935 & & & \\
Loyalty & 0.495 & 0.422 & 0.523 & 0.407 & 0.441 & 0.507 & 0.707 & & \\
PI & 0.565 & 0.719 & 0.639 & 0.644 & 0.459 & 0.510 & 0.508 & 0.848 & \\
RI & 0.538 & 0.599 & 0.638 & 0.630 & 0.448 & 0.495 & 0.595 & 0.736 & 0.858 \\
\hline
\end{tabular}

Source: Own research work processed in PLS-SEM

Table 5 shows that our model has ultimately attained the discriminant validity and having values less than 1 which illustrates that there is a positive Discriminant Validity.

\subsection{Model Fit}

The measurement model has a good fit. For SRMR, a value of less than 0.10 or $0.08(\mathrm{Hu}$ and Bentler, 1999) is considered a good fit. NFI Value greater than 0.80 suggests a good fit: NFI $=0.7, \mathrm{SRMR}=0.12$.

Table 6. Fit summary

\begin{tabular}{lll}
\hline & Saturated Model & Estimated Model \\
\hline SRMR & 0.057 & 0.129 \\
d_ULS & 0.992 & 5.022 \\
d_G & 0.656 & 0.918 \\
Chi-Square & $1,208.004$ & $1,434.758$ \\
NFI & & 0.662 \\
\hline
\end{tabular}

Source: Own research work processed in PLS-SEM

\subsection{Structural Model}

The hypothesis was tested using the bootstrapping function of PLS-SEM software. The criteria on which the hypothesis tested was two-tailed p-value testing. The confidence interval used as $\alpha 0.1$ as recommended by Fisher, according to him $0.1,0.05,0.01,0.001$ can be used as $\alpha$ when conducting a significance test. 


\section{$\Lambda$ Macrothink}

\subsubsection{Direct Effect}

Structure model clearly shows the impact of CSR, positive moral emotions AGE awe, attitude, brand attitude and CCI on consumer response (loyalty, purchase intention and recommend intention). With the help of boot strapping, all the extracted values (Table 7) clarify that CSR having direct positive relationship with purchase intention and recommend intention $(\beta=$ $0.20 ; \mathrm{t}=3.27),(\beta=0.29 ; \mathrm{t}=4.35)$ whereas loyalty has negative relationship $(\beta=0.04 ; \mathrm{t}=$ $0.50)$, positive moral emotions awe having direct insignificant relationship with purchase intention, recommend intention and loyalty $(\beta=0.05 ; \mathrm{t}=0.72),(\beta=0.05 ; \mathrm{t}=0.76)(\beta=0.12$; $\mathrm{t}=1.51)$ respectively, gratitude has also significant relationship with purchase intention and recommend intention $(\beta=0.05 ; \mathrm{t}=0.75),(\beta=0.08 ; \mathrm{t}=1.06)$ while loyalty has insignificant impact $(\beta=0.21 ; \mathrm{t}=3.02)$, elevation similarly has negative relationship with purchase intention, recommend intention and loyalty respectively $(\beta=0.06 ; \mathrm{t}=0.92),(\beta=0.04 ; \mathrm{t}=$ $0.70)$ and $(\beta=0.06 ; \mathrm{t}=0.69)$, attitude has positive significant relationship with purchase intention, recommend intention $(\beta=0.37 ; \mathrm{t}=5.47),(\beta=0.15 ; \mathrm{t}=2.05)$ and loyalty has negative relationship $(\beta=0.05 ; \mathrm{t}=0.67)$, CCI has greater positive connection with purchase intention, recommend intention and loyalty respectively $(\beta=0.33 ; \mathrm{t}=4.80),(\beta=0.26 ; \mathrm{t}=$ 4.89), $(\beta=0.28 ; \mathrm{t}=3.28)$ It also illustrates that CSR has direct positive impact on positive moral emotions AGE awe $(\beta=0.55, \mathrm{t}=8.86)$, gratitude $(\beta=0.46, \mathrm{t}=6.38)$ elevation $(\beta=$ $0.37, \mathrm{t}=5.33)$, attitude $(\beta=0.63 ; \mathrm{t}=12.23)$, and $\mathrm{CCI}(\beta=0.47 ; \mathrm{t}=7.57)$, thus leading to the acceptance of H1a-1c, H2, H3, and H4.

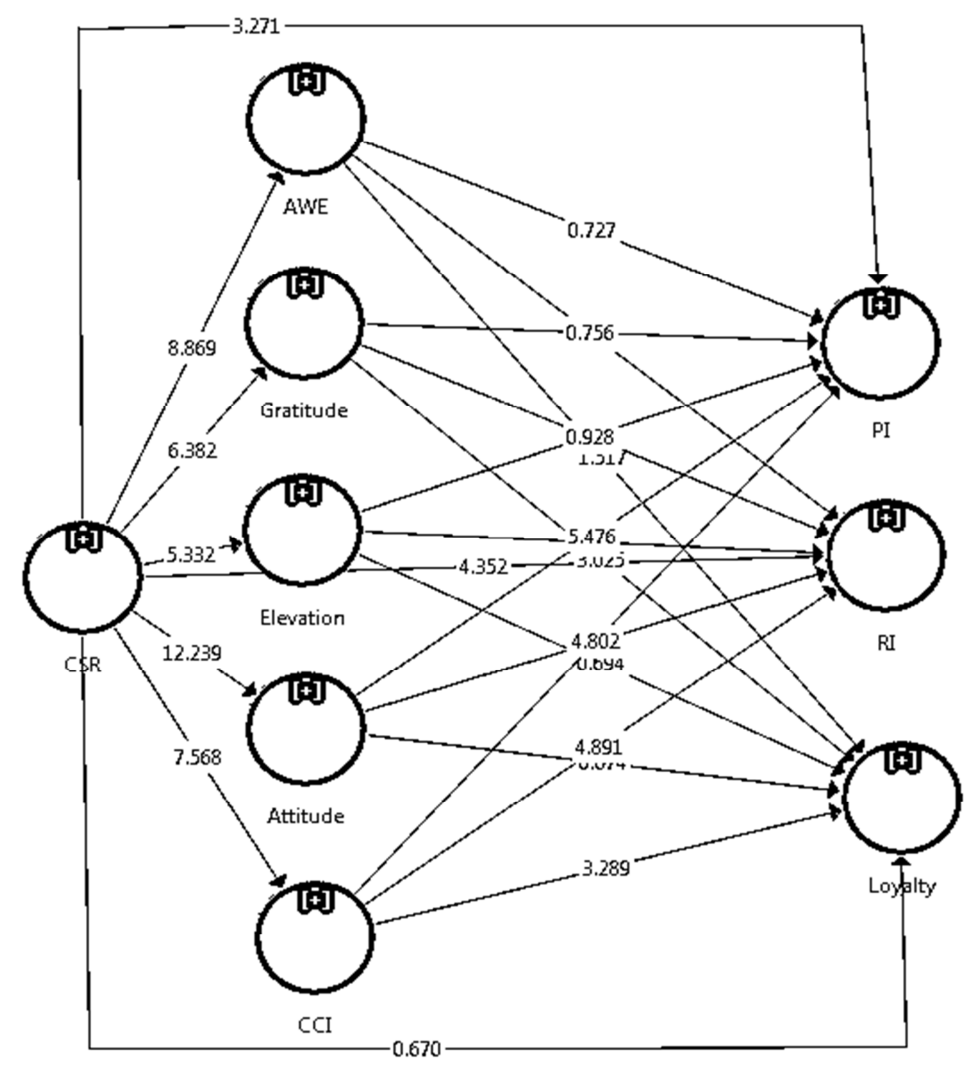

Figure 2. Structural Model

Source: Own research work processed in PLS-SEM 


\section{Macrothink}

\subsubsection{Significant Mediating Effect}

CCI seems to positively and significantly mediate the effect of CSR on Loyalty, PI, and RI. Similarly, Attitude also has a significant mediating role in CSR relationship with RI and PI. Lastly, CSR and PI nexus is also mediated by Attitude

Table 7. Path Coefficient

\begin{tabular}{llllll}
\hline & $\begin{array}{l}\text { Original } \\
\text { Sample }(\mathbf{O})\end{array}$ & $\begin{array}{l}\text { Sample } \\
\text { Mean }(\mathbf{M})\end{array}$ & $\begin{array}{l}\text { Standard } \\
\text { Deviation } \\
\text { (STDEV) }\end{array}$ & $\begin{array}{l}\text { T Statistics } \\
(|\mathbf{O} / \mathbf{S T D E V}|\end{array}$ & P Values \\
\hline CSR -> CCI -> Loyalty & 0.134 & 0.138 & 0.05 & 2.716 & 0.007 \\
CSR -> Gratitude -> Loyalty & 0.097 & 0.099 & 0.036 & 2.727 & 0.006 \\
CSR -> Attitude -> PI & 0.238 & 0.234 & 0.047 & 5.111 & 0 \\
CSR -> CCI -> PI & 0.123 & 0.124 & 0.031 & 3.945 & 0 \\
CSR-> Attitude -> RI & 0.098 & 0.095 & 0.05 & 1.956 & 0.051 \\
CSR -> CCI -> RI & 0.158 & 0.161 & 0.044 & 3.601 & 0 \\
\hline
\end{tabular}

Source: Own research work processed in PLS-SEM

\subsection{Hypotheses Testing}

Table 8. Hypotheses

\begin{tabular}{|c|c|c|c|c|}
\hline Hypotheses & Constructs & T Statistics & P-Value & Status \\
\hline H1a & $\mathrm{CSR} \rightarrow$ Purchase intention & 3.27 & 0.000 & Accept \\
\hline $\mathrm{H} 1 \mathrm{~b}$ & $\mathrm{CSR} \rightarrow$ Recommend Intention & 4.35 & 0.001 & Accept \\
\hline $\mathrm{H} 1 \mathrm{c}$ & $\mathrm{CSR} \rightarrow$ Loyalty & 0.67 & 0.503 & Reject \\
\hline $\mathrm{H} 2 \mathrm{a}$ & $\mathrm{CSR} \rightarrow$ Awe & 8.86 & 0.000 & Accept \\
\hline $\mathrm{H} 2 \mathrm{~b}$ & $\mathrm{CSR} \rightarrow$ Gratitude & 6.38 & 0.000 & Accept \\
\hline $\mathrm{H} 2 \mathrm{c}$ & $\mathrm{CSR} \rightarrow$ Elevation & 5.33 & 0.000 & Accept \\
\hline H3 & $\mathrm{CSR} \rightarrow$ Attitude & 12.23 & 0.000 & Accept \\
\hline H4 & $\mathrm{CSR} \rightarrow \mathrm{CCI}$ & 7.57 & 0.000 & Accept \\
\hline $\mathrm{H} 5 \mathrm{a}$ & $\mathrm{CSR} \rightarrow$ Awe $\rightarrow$ Purchase Intention & 0.70 & 0.483 & Reject \\
\hline $\mathrm{H} 5 \mathrm{~b}$ & $\mathrm{CSR} \rightarrow$ Awe $\rightarrow$ Recommend Intention & 0.72 & 0.466 & Reject \\
\hline $\mathrm{H} 5 \mathrm{c}$ & $\mathrm{CSR} \rightarrow$ Awe $\rightarrow$ Loyalty & 1.43 & 0.151 & Reject \\
\hline H6a & $\mathrm{CSR} \rightarrow$ Gratitude $\rightarrow$ Purchase Intention & 0.71 & 0.477 & Reject \\
\hline $\mathrm{H} 6 \mathrm{~b}$ & $\mathrm{CSR} \rightarrow$ Gratitude $\rightarrow$ Recommend Intention & 1.00 & 0.315 & Reject \\
\hline H6c & $\mathrm{CSR} \rightarrow$ Gratitude $\rightarrow$ Loyalty & 2.72 & 0.006 & Accept \\
\hline $\mathrm{H} 7 \mathrm{a}$ & $\mathrm{CSR} \rightarrow$ Elevation $\rightarrow$ Purchase Intention & 0.90 & 0.366 & Reject \\
\hline $\mathrm{H} 7 \mathrm{~b}$ & $\mathrm{CSR} \rightarrow$ Elevation $\rightarrow$ Recommend Intention & 0.68 & 0.498 & Reject \\
\hline $\mathrm{H} 7 \mathrm{c}$ & $\mathrm{CSR} \rightarrow$ Elevation $\rightarrow$ Loyalty & 0.65 & 0.512 & Reject \\
\hline $\mathrm{H} 8 \mathrm{a}$ & $\mathrm{CSR} \rightarrow$ Attitude $\rightarrow$ Purchase Intention & 5.11 & 0.000 & Accept \\
\hline
\end{tabular}




\begin{tabular}{lllll}
\hline H8b & CSR $\rightarrow$ Attitude $\rightarrow$ Recommend Intention & 1.96 & 0.050 & Accept \\
H8c & CSR $\rightarrow$ Attitude $\rightarrow$ Loyalty & 0.66 & 0.509 & Reject \\
H9a & CSR $\rightarrow$ CCI $\rightarrow$ Purchase Intention & 3.94 & 0.000 & Accept \\
H9b & CSR $\rightarrow$ CCI $\rightarrow$ Recommend Intention & 3.60 & 0.000 & Accept \\
H9 & CSR $\rightarrow$ CCI $\rightarrow$ Loyalty & 2.71 & 0.007 & Accept \\
\hline
\end{tabular}

Source: Own research work processed in PLS-SEM

To measure the impact of CSR on purchase intention, recommend intention and loyalty, awe, gratitude, elevation, attitude and $\mathrm{CCI}$; H1a-c, H2a-c, H3, and $\mathrm{H} 4$ were expressed as $\mathrm{T}=3.27$, $4.35,0.67,8.86,6.38,5.33,12.33$ and 7.57 respectively $(\mathrm{T}>1.96)$ whereas $\mathrm{P}<0.05$ hence we are accepting all alternative hypotheses except $\mathrm{H} 1 \mathrm{c}$ since $(\mathrm{T}<1.96)$. On the other hand, H5a-c, H6a-b and H7a-c were also formulated to analyze the power of awe, gratitude and elevation on purchase intention, recommend intention and loyalty, Findings show that these variables have no impact on PI, RI, loyalty as $(\mathrm{T}<1.96)$ and $\mathrm{P}>0.05$ so consequently we are rejecting these hypotheses since all the values are insignificant. Similarly, for analyzing the effect of attitude and CCI on PI, RI and loyalty; H8a-c and H9a-c we examined the relationship between them, the findings revealed there is positive and significant impact as $(T>1.96)$ while $\mathrm{P}<0.05$ thus accepting all our hypotheses but there is one insignificant hypothesis we are rejecting $\mathrm{H} 8 \mathrm{c}$ since $(\mathrm{T}<1.96)$ and $\mathrm{P}>0.05$.

\section{Discussions and Conclusion}

\subsection{Discussions}

This study draws the following result: first, CSR has significant positive effects on consumer response in Pakistan, but the impact of these are distinctive from one another including PI, RI, and Loyalty. Both PI and RI have the highest impact, whereas loyalty has the lowest. Both PI and RI have the highest impact, whereas loyalty has the lowest impact. Secondly, Positive moral emotions AGE, attitude and CCI play a crucial mediating role between CSR and consumer response PI, RI and Loyalty, but AGE doesn't make a mediating effect among CSR and consumer response similarly, attitude significantly having good mediation effect excluding the mediation between CSR and loyalty. Additionally, CSR is having an indirect positive effect on PI, RI, and loyalty via Consumer-Company Identification. Corporations should spread and communicate their characteristics concisely, logically and in an influential way if CCI is considered necessary. Meanwhile, all the CSR actions and brands are witnessed by the consumers so positive response is predicted towards the brand and their CSR initiatives. Therefore, our paper has a similar result that attitude is having a strong mediation among CSR, PI, RI and excluding loyalty because it doesn't make a significant relationship. Though it was revealed that AGE has no mediation impact between CSR, PI, RI and loyalty which helps in gaining an insight that companies should evoke other different emotions to get positive reactions from the consumers. Similarly, CSR initiatives are directly proportional to the buying intention of customers in developing countries like Pakistan. Our results illustrate that all those corporate bands performing greater CSR activities will have a decisive relationship with PI, RI and Loyalty directly which shows all the corporations should 
maximize their CSR activities to entice more consumers of the products by inducing their positive responses towards a brand which leads to increase their sales and revenue as a result.

\subsection{Conclusion}

The objective of this study is to measure the effect of CSR actions on consumer response (PI, RI, Loyalty). However, we concluded that emotions such as awe, gratitude, \& elevation are not considered to be the exact consumer responses to their activities, whereas CCI and attitudes play a crucial part in identifying consumer response (PI, RI, and loyalty). Concisely these feelings awe, gratitude, \& elevation are not even the important positive states for consumers, and they are not attracted to sharing their feelings of happiness and joy, as well as not responding to appreciating the companies and their products. Another difference of opinion came to be noticed that CCI plays a crucial part as a mediator between proposed relationships. Consequently, we have contributed one thing i.e. CCI and attitude both trigger positive reactions of the consumers towards the companies CSR actions whereas awe, gratitude, and elevation failed in inducing consumer reactions. The second contribution was to develop a mediation between the companies' CSR activities and consumer response to their activities. Our findings aid the mediation process of attitude and CCI excluding positive moral emotions. An investigation has been done and few scholars have given utmost importance to a consumer \& brand connection by assessing how consumer emotions, feelings, and ethical decisions affected through CSR activities by corporations. There is another gap in this current study that needs to be analyzed both attitude, emotions and CCI to comprehend the consumer reactions towards CSR. The third contribution was to investigate the mediation effect of Awe, Gratitude, and Elevation individually between CSR, PI, RI and Loyalty which is also a gap in the previous research study where AGE altogether was considered as positive moral emotions and results were positive whereas, in current research, to examine the individual effect of each positive moral emotion AGE between CSR and PI, RI and loyalty results revealed an insignificant and negative effect.

\subsection{Implication}

This paper has significant suggestions specifically for the companies since they need to understand the influence of both perceptive methods and CCI on consumer responses towards CSR activities, they both are so important in building stronger customer-brand associations. Many approaches have been required to emphasize more on consumer's expressive and attitudinal responses. While designing CSR programs, companies should focus on the management of consumer identification. Corporations should focus on different positive emotions other than awe, gratitude, and elevation because it does not influence consumer response towards the corporate brand. Even though it could be so hard for the companies to arouse nonetheless they extend the consumer's focus once induced. Consumers, for example, can be encouraged via AGE emotions which enable them to recognize the company and make enough investment. In this way, corporate brands must devise various strategies to induce several emotions in them by spreading their societal activities in different ways. In short, Corporations should not only consider CSR as an important tool to enhance consumer purchase intention for the short term but also maintain long term relationships with the 
consumer. For instance, making these consumers brand ambassadors of the products and spreading positive WOM to entice more potential clients and therefore building a cordial relationship with them.

\subsection{Limitation of the Study}

Although the research paper reached its target, unfortunately, it also has some limitations. Firstly, while conducting research there was a certain limitation of time, the study wouldn't be possible to target many people. Hence the research was restricted to a limited number of respondents having a sample size of 300 via online and hardcopy questionnaires were provided. Moreover, it was conducted in Karachi which doesn't have a variety of information and statistics, hence more cities should be targeted like Islamabad, Lahore, Faisalabad to get maximum responses from the consumers in different cities and to gather diverse data.

\section{Acknowledgment}

I would like to extend appreciation and gratitude to my supervisor Dr. Danish Ahmed Siddiqui for the encouragement, guidance and constant support in doing research.

Special thanks to my classmates for providing valuable knowledge, information and unconditional assistance throughout the research.

This research received no specific grant from any funding agency in the public, commercial, or not-for-profit sectors.

\section{References}

Algoe, S., \& Haidt, J. (2009). Witnessing Excellence in Action: The other-praising emotions of elevation, admiration, and gratitude. Journal of Positive Psychology, 4, 105-127. https://doi.org/10.1080/17439760802650519

Ali, I. (2011). Influence of corporate social responsibility on the development of corporate reputation and customer purchase intentions. Romanian Review of Social Sciences, 1, 19-26.

Ali, B. M., \& Yusef, M. (2011). Islamic bank and corporate social responsibility (CSR). Islamic Management Business, 5(11), 194-209.

Anderson, J. C., \& Gerbing, D. W. (1988). Structural equation modeling in practice: A review and recommended two-step approach. Psychological Bulletin, 103(3), 411-423. https://doi.org/10.1037/0033-2909.103.3.411

Ashforth, B. E., \& Mael, F. (1989). Social identity theory and the organization. Academy of Management Review, 14(1), 20-39. https://doi.org/10.5465/amr.1989.4278999

Bagozzi, R. P., Joham, B., \& Youjae, Y. (1988). An Investigation into the Role of Volitions as Intervening Variables in the Atitude-Behavior Relationship. Unpublished working paper, The University of Michigan.

Boccia, F., \& Sarnacchiaro, P. (2017). The Impact of Corporate Social Responsibility on Consumer Preference: A Structural Equation Analysis. Corporate Social Responsibility and 
Environmental Management, 25(2), 151-163 https://doi.org/10.1002/csr.1446

Brown, T. J., \& Dacin, P. A. (1997). The company and the product: Corporate associations and consumer product responses. Journal of Marketing, 61(1), 68-84. https://doi.org/10.2307/1252190

Chin, W., \& Marcoulides, G. (1998). The Partial Least Squares Approach to Structural Equation Modeling. Modern Methods for Business Research, 8.

Chomvilailuk, R., \& Butcher, K. (2014). Effects of quality and corporate social responsibility on loyalty. The Service Industries Journal, 34(11), 938-954. https://doi.org/10.1080/02642069.2014.915952

Chung, K., Yu, J.-E., Choi, M.-G., \& Shin, J.-I. (2015). The Effects of CSR on Customer Satisfaction and Loyalty in China: The Moderating Role of Corporate Image. Journal of Economics, Business and Management, 3, 542-547. https://doi.org/10.7763/JOEBM.2015.V3.243

Dabholkar, P. A., \& Bagozzi, R. P. (2002). An attitudinal model of technology-based self-service. Moderating effects of consumer traits and situational factors. Journal of the Academy of Marketing Science, 30(3), 184-201. https://doi.org/10.1177/0092070302303001

Dawkins, J., \& Lewis, S. (2003). CSR in Stakeholder Expectations: And Their Implication for Company Strategy. Journal of Business Ethics, 44, 185-193. https://doi.org/10.1023/A:1023399732720

Du, S., Bhattacharya, C. B., \& Sen, S. (2010). Maximizing business returns to Corporate Social Responsibility (CSR): The role of CSR communication. International Journal of Management Review, 12(1), 8-19. https://doi.org/10.1111/j.1468-2370.2009.00276.x

Gelb, D. S., \& Strawser, J. A. (2001). Corporate Social Responsibility and Financial Disclosures: An Alternative Explanation for Increased Disclosure. Journal of Business Ethics, 33(1), 1-13. https://doi.org/10.1023/A:1011941212444

Hair, J. F., Anderson, R. E., Tatham, R. L., \& William, C. B. (2010). Multivariate data analysis. New Jersey: Pearson.

Hair, J., Black, B., Babin, B., Anderson, R., \& Tatham, R. (2006). Multivariate Data Analysis (6th ed.). Upper Saddle River, NJ: Prentice-Hall.

He, H., \& Li, Y. (2011). CSR and service brand: The mediating effect of brand identification and moderating effect of service quality. Journal of Business Ethics, 100(4), 673-688. https://doi.org/10.1007/s10551-010-0703-y

Herpen, E. V., Pennings, J. M. E., \& Meulenberg, M. (2003). Consumers, evaluations of socially responsible activities in retailing. Mansholt Working Paper, 4(6).

Hu, L.-T., \& Bentler, P. M. (1999). Cutoff criteria for fit indexes in covariance structure analysis: Conventional Criteria Versus New Alternatives. Structural Equation Modeling, 6(1), 1-55. https://doi.org/10.1080/10705519909540118 
Lichtenstein, D., Drumwright, M., \& Braig, B. (2004). The effect of corporate social responsibility on customer donations to corporate-supported nonprofits. Journal of Marketing, 68(4), 16-32. https://doi.org/10.1509/jmkg.68.4.16.42726

Lii, Y. S., \& Lee, M. (2012). Doing right leads to doing well: When the type of CSR and reputation interact to affect consumer evaluations of the firm. Journal of Business Ethics, 105(1), 69-81. https://doi.org/10.1007/s10551-011-0948-0

López, S., \& Smith, N. (2014). Consumers and CSR understanding: Nuances in consumer perceptions of corporate responsibility initiatives. In R. P. Hill \& R. Lagan (Eds.), Handbook of research on marketing and corporate social responsibility (pp. 219-233). Cheltenham, UK: Edward Elgar Publishing. https://doi.org/10.1016/j.sjme.2016.06.002

Luffarelli, J., \& Awaysheh, A. (2018). The Impact of Indirect Corporate Social Performance Signals on Firm Value: Evidence from an Event Study. Corporate Social Responsibility and Environmental Management, 25(3), 295-310 https://doi.org/10.1002/csr.1468

Lynch, J., \& Chernatony, L. D. (2004). The power of emotion: Brand communication in business-to-business markets. Journal of Brand Management, 11(5), 403-419. https://doi.org/10.1057/palgrave.bm.2540185

Matute - Vallejo, J., Bravo, R., \& Pina, J. M. (2011). The influence of corporate social responsibility and price fairness on customer behaviour: evidence from the financial sector. Corporate Social Responsibility and Environmental Management, 18(6), 317-331. https://doi.org/10.1002/csr.247

Netemeyer, R. G., Krishnan, B., Pullig, C. et al. (2004). Developing and validating measures of facets of customer-based brand equity. Journal of Business Research, 57(2), 209-224. https://doi.org/10.1016/S0148-2963(01)00303-4

Pérez, A., \& del Bosque, I. R. (2015). How customers construct corporate social responsibility images: Testing the moderating role of demographic characteristics. Business Research Quarterly, 18(2), 127-141. https://doi.org/10.1016/j.brq.2014.04.003

Perrini, F., Castaldo, S., Misani, N., \& Tencati, A. (2010). The impact of corporate social responsibility associations on trust in organic products marketed by mainstream retailers: A study of Italian consumers. Business Strategy and the Environment, 19(8), 512-526. https://doi.org/10.1002/bse.660

Pomering, A., \& Dolnicar, S. (2009). Assessing the prerequisite of successful CSR implementation: Are consumers aware of CSR initiatives? Journal of Business Ethics, 85(2), 285-301. https://doi.org/10.1007/s10551-008-9729-9

Romani, S., Grappi, S., \& Bagozzi, R. P. (2013). Explaining consumer reactions to corporate social responsibility: The role of gratitude and altruistic values. Journal of Business Ethics, 114(2), 193-206. https://doi.org/10.1007/s10551-012-1337-z

Safi, A., \& Ramay, M. (2013). Corporate social responsibility and consumer behavior: A study from Pakistan. Information Management and Business Review, 5(4), 194-202. 
https://doi.org/10.22610/imbr.v5i4.1043

Saleh, M. H. T., Ebeid, A. Y., \& Abdel hameed, T. A. (2015). Customers' perception of corporate social responsibility (CSR): its impact on word-of-mouth and retention. Innovative Marketing, 11(2), 49-55.

Salmones, M., Crespo, A., \& Bosque, I. (2005). Influence of corporate social responsibility on loyalty and valuation of service. Journal of Business Ethics, 61, 369-385. https://doi.org/10.1007/s10551-005-5841-2

Schmeltz, L. (2012). Consumer-oriented CSR communication: Focusing on ability or morality? Corporate Communications: An International Journal, 17, 29-49. https://doi.org/10.1108/13563281211196344

Siu, N. Y. M., Zhang, T. J. F., \& Kwan, H. Y. (2014). Effect of corporate social responsibility, customer attribution and prior expectation on post-recovery satisfaction. International Journal of Hospitality Management, 43, 87-97. https://doi.org/10.1016/j.ijhm.2014.08.007

Spears, N., \& Singh, S. N. (2004). Measuring attitude toward the brand and purchase intentions. Journal of Current Issues and Research in Advertising, 26(2), 53-66. https://doi.org/10.1080/10641734.2004.10505164

Staudt, S., Shao, C. Y., Dubinsky, A. J., \& Wilson, P. H. (2014). Corporate Social Responsibility, Perceived Customer Value, and Customer-Based Brand Equity: A Cross-National Comparison.

Turker, D. (2008). Measuring Corporate Social Responsibility: A Scale Development Study. Journal of Business Ethics, 85(4), 411-427. https://doi.org/10.1007/s10551-008-9780-6

Vahdati, H., \& Mousavi Nejad, S. H. (2016). Brand personality toward customer purchase intention: The intermediate role of electronic word-of-mouth and brand equity. Asian Academy of Management Journal, 21(2), 1-26. https://doi.org/10.21315/aamj2016.21.2.1

Wang, D., Chen, P.-H., Yu, T., \& Hsiao, C.-Y. (2015). The effects of corporate social responsibility on brand equity and firm performance. Journal of Business Research, 68. https://doi.org/10.1016/j.jbusres.2015.06.003

Wu, W. Y., \& Tsai, C. H. (2007). The empirical study of CRM consumer-company identification and purchase intention in the direct selling industry. International Journal of Commerce \& Management, 17(3), 194-210. https://doi.org/10.5539/ijms.v7n5p33

Xie, C., Bagozzi, R. P., \& Grønhaug, K. (2015). The role of moral emotions and individual differences in consumer responses to corporate green and non-green actions. Journal of the Academy of Marketing Science, 43, 333-356. https://doi.org/10.1007/s11747-014-0394-5

Zeithaml, V. A., Berry, L., \& Parasuraman, A. (1996). The behavioral consequence of service quality. Journal of Marketing, 60(2), 31-46. https://doi.org/10.2307/1251929 


\section{Macrothink}

\section{Copyrights}

Copyright for this article is retained by the author(s), with first publication rights granted to the journal.

This is an open-access article distributed under the terms and conditions of the Creative Commons Attribution license (http://creativecommons.org/licenses/by/4.0/). 